Research, part of a Special Feature on Implementing Participatory Water Management: Recent Advances in Theory, Practice and Evaluation

\title{
Beyond Dry Feet? Experiences from a Participatory Water-Management Planning Case in The Netherlands
}

\author{
Machiel Lamers $^{1}, \underline{\text { Bouke Ottow }}^{2}, \underline{\text { Greet Francois }}^{3}$, and $\underline{\text { Yorck von Korff }}^{4}$
}

\begin{abstract}
Participation of stakeholders in planning processes is increasingly seen as an essential element in adaptive and integrated water management and sometimes a policy requirement from higher-level governance bodies. Despite an extensive literature on the advantages and disadvantages of public participation and criteria for effective participation, not much is known about how water managers should proceed in a given context. Water-management agencies have to face the challenge of effectively involving stakeholders in developing their water-management plans and must design and implement a balanced process approach among the available time, finances, organization, and facilitation without compromising their authority. This article presents a participatory planning process designed and implemented at Water Board "Hoogheemraadschap De Stichtse Rijnlanden" (HDSR) in the center of The Netherlands. For a period of 2 yrs, these three groups were involved in various ways, participating in different types of meetings and workshops, using a range of participatory tools and techniques. The process and results of the three groups were monitored and evaluated using a tailored evaluation strategy. This paper analyzes the way the design and implementation of the process is perceived by both the conveners and participants and suggests practical lessons for water managers. Based on our case, it is argued that a careful process design, a thorough and continuous stakeholder analysis, building reflective workshops within and after the process, and ensuring experienced and qualified process leaders can greatly enhance the adaptive capacity and successful outcome of the participatory planning process.
\end{abstract}

Key Words: participatory planning; process design; public participation; water management

\section{INTRODUCTION}

Water boards are regional water agencies responsible for the quantity and quality of surface water in the Netherlands (Mostert 2006). Dutch water boards are facing the challenge of developing regional water plans and addressing long-term qualitative and quantitative issues. The Dutch water policy directive (Nationaal Bestuursakkoord Water) requires that regional water management plans anticipate water shortages and floods; integrate different functions and interests related to water in the region; and create a good ecological status for the water system as stipulated by the European Water Framework Directive (WFD) (Hoogheemraadschap De Stichtse Rijnlanden (HDSR) 2003). Together with municipalities and the provinces, water boards must implement these objectives by 2015 in widely supported water management plans (WAPs) and urban water plans. Actively involving the public and interested stakeholders in water management planning is a policy requirement from higher-level governance bodies, as outlined in Article 14 of the 2000 WFD (Newig and Pahl-Wostl 2005). Although this stipulation is open and leaves room for interpretation, requiring stakeholder involvement of some kind can be seen as a good step forward. This article presents a case study on how these policies are unfolding in the Netherlands.

The concept of public participation, or the collaboration between governmental and nongovernmental stakeholders (Huitema et al. 2009), 
is related to a range of similar meaning concepts, such as collaboration (Gray 1996) and multistakeholder platforms (Warner 2005). Participation in policy processes can take various forms, ranging from information (i.e., transparency) to consultation (i.e., input from the public) to designing policy (i. e., co-designing) to shared decision making (i.e., codeciding) (Hare et al. 2003). These different forms of participation are typically represented as a ladder (Arnstein 1969, Geurts and Mayer 1996) or as a continuum (Creighton 2005, Warner and Verhallen 2007). The diversity of concepts and meanings can cause confusion for water managers (Rowe and Frewer 2004).

Public participation is deemed an essential element in developing adaptive and integrated water management (Pahl-Wostl et al. 2007, Watson 2007, Huitema et al. 2009). Stakeholders' participation is believed to be necessary for developing wellbalanced plans with wider societal support, creating transparency for the public, and allowing smoother policy implementation (Creighton 2005, Healy 2006). However, several authors show that the merits of organized public participation are not selfevident: there are limits to public participation, and the democratic virtues are questionable (Meadowcroft 1998, van der Arend 2007). Optimal representation of all interests would include everyone affected by the process, but this is often practically and financially impossible (Geurts and Mayer 1996, Meadowcroft 1998). Sometimes groups do not want to participate (Warner 2005). In the early stages of the discussion process, an issue may not be in a state where it can be understood easily by the public (Rowe and Frewer 2000), which leads to confusion over aims and focus. The diversity in discourses in the group-formal authorities, water technicians, user-group representatives, and the public-is considerable, and makes open discussion difficult (Healy 2006). Furthermore, a diversity of participants having a direct influence on policy outcome can lead to power struggles, as not every stakeholder shares the same interests and is willing to share influence (Meadowcroft 1998, Warner 2005). Additionally, participants vary in how much time and effort they are willing to invest in the participatory process. If not managed adequately, this may lead to frustration, stakeholder fatigue, and drop-out (Rowe and Frewer 2000).

One relevant question is how a "successful" or "effective" process can be characterized by fixed normative criteria that would apply in different contexts (e.g., Webler 1995, Glicken 2000, Rowe and Frewer 2000, Syme and Nancarrow 2002, Marks 2004, Rowe and Frewer 2004)? A large body of work evaluates participatory programs in various fields (i.e., integrated water resources management (IWRM), natural resources management (NRM), risk management) in case studies (e.g., Renn 1999, Webler and Tuler 2001), case surveys (e.g., Lynn and Busenberg 1995, Beierle and Cayford 2002), and theory-derived perspectives (e.g., Webler 1995, Marks 2004). Some criteria, such as "fairness" and "competence", can provide guidance for process designers, but other criteria tell designers and implementers little about how they should proceed in different situations. Some suggest that it is beneficial to employ a combination of different methods and participatory groups in larger participatory programs (see for example Beierle and Cayford 2002, Creighton 2005), but there is little evidence to support this. It is insufficiently known how to design and implement a public participation program in different settings that optimizes these conflicting criteria.

In this article, we address this knowledge gap by presenting observations and evaluation results from a Dutch case study. Between 2005 and 2008, the HDSR - a water board in the center of the Netherlands-developed a water management plan for the Kromme Rijn region in cooperation with other water authorities, user interest groups, and the wider public. Table 1 provides some basic details on land use in the Kromme Rijn region. Cattle farmers require a steady water supply, and an increasing number of fruit farmers need large quantities of surface water $\left(26,000 \mathrm{~m}^{3}\right.$ an hour) during frosty nights in spring to prevent fruit tree buds from freezing. The current dam and pumps are only capable of bringing a maximum of $720 \mathrm{~m}^{3}$ of water an hour in the Kromme Rijn region, which causes large fluctuations in surface water level (Koenraadt et al. 2008). The relatively limited infrastructure of river basins, canals, and ditches can hardly discharge the water in cases of heavy rain and cannot deliver the massive quantities of water when the fruit farmers require it. Water supply is already a problem when surface water levels are low during the dry summer months. Judging from the effects of climate change and growth trends in this sector, water quantity issues will likely become more difficult to manage (Koenraadt et al. 2008). 
Table 1. Land use in the Kromme Rijn region.

\begin{tabular}{lcc}
\hline \hline Land use & Surface area (in hectares) & Percentage (\%) \\
\hline Fruit farming & 816 & 14 \\
Dairy farming & 2,616 & 44 \\
Other agriculture & 637 & 11 \\
Urban area and infrastructure & 1,673 & 28 \\
Nature & 144 & 2 \\
Open water & 74 & 1 \\
Total & 5,924 & 100 \\
\hline
\end{tabular}

Both the practice of water delivery and the participatory planning approach go beyond the traditional responsibility of the water board, which is to drain the superfluous water from the land, or -in their own words - to keep "dry feet."

The public participation program, which was codesigned and executed by the HDSR and the authors, addressed the needs of organizers and participants. The water board had to reconcile different types of stakeholder interests in water management, from personal stakes, to sectoral economic interests, and collective societal interests. The presence of the public during strategic discussions among authorities and stakeholder organizations was considered undesirable, creating an uncertain and unsafe environment (i.e., emotional reactions and interventions). However, involvement of different stakeholders (such as the public) was considered important to ensure that all interests were addressed and that support was generated for the water management plan. These participation dilemmas were considered by the water board before the project's design phase (Holtman et al. 2005).

Based on the range of interests at stake, the project objective, the timeframe, and the resources available, the organizer decides if pubic participation is required, whom to involve in what capacity, how many meetings to have, and what form these meetings will take (Creighton 2005).
Many practical mapping tools are available to categorize stakeholders (see for example the work by Eden 1996, European Communities 2003, HarmoniCOP 2005) and provide guidance on stakeholder involvement, based on interest and influence. The interests of individuals and organizations relate to the extent to which they are affected by the objective of the water management planning process. The influence of individuals or organizations relates to the level of influence these actors can exercise on the outcome and implementation of the planning process. Using the bull's eye approach (European Communities 2003) stakeholders were categorized according to importance for the project, from central to more peripheral, thereby providing guidance to planners in making decisions about stakeholder involvement. The stakeholder analysis was carried out by the planning group, consisting of water board employees, and facilitated by one of the authors. Stakeholders were mapped in four different groups, i.e., a core group of formal water authorities, an advisory group of stakeholder representatives, regional residents, and an information group of stakeholders who were only informed about the progress made. This categorization was presented to a wider group of stakeholders and adjustments were published in a newsletter (see Table 2). As it was deemed necessary to involve the public, as well as user-group representatives, it was decided to involve all four groups in different ways. 
Table 2. Different groups in the Kromme Rijn participation process.

\begin{tabular}{ll}
\hline The core group & $\begin{array}{l}\text { The core group of formal authorities involved in the project, jointly responsible for the } \\
\text { development of the regional water plan, and sharing the strategic coordination of the } \\
\text { process. The core group consisted of the representatives of the Province, the Water } \\
\text { Board, and the three Municipalities covering the project region. }\end{array}$ \\
The advisory group of influential and interested stakeholders from the region and the \\
central platform for discussion about the project. Besides the representatives from \\
agricultural organizations, environmental and recreation groups, the members of the core \\
group were also part of this group.
\end{tabular}

The assembling of the groups was based on levels of interest, with the more central groups being nested in the peripheral groups (see Fig. 1). The design would take into account the polycentric and nested character of the Dutch regional water governance structure (Groot et al. 2002, Mostert 2006, Moellenkamp et al. 2007). This would allow each group to participate differently, with a different role and objective, extent and methodology of participation, and set of issues to deal with. This system allowed the stakeholders formally responsible for collective water interests (i.e., the water board, municipalities, province), sectoral economic interests (i.e., agriculture, fruit farming, environment, recreation), and individual interests (i.e., citizens) to participate productively in a structured setting. It was anticipated that this would stimulate optimal horizontal communication (i.e., between members of the same group with similar types of interests). This design simultaneously ensured that the groups were integrated by participation and communication, allowing for vertical communication (i.e., between groups). The participatory element allowed members of the central groups to participate in meetings of the peripheral groups to learn about the views, attitudes, and reactions to the WMP. The importance of this "boundary crossing" in the facilitation of participation of multiple nested systems is raised by Groot et al. (2002). Communication by the planning group to the different groups, through presentations, newsletters, and website updates, formed an important central pillar in this project design. The process design (see Fig. 2) was laid down in a project plan by the planning group (Holtman et al. 2005).

With this design, the water board aimed to have a successful participatory process, leading to a widely accepted and realistic water management plan, tailored to the regional context and the needs of the stakeholders involved. The central question this article seeks to answer is the extent to which the water board has succeeded in reaching these objectives. How was the chosen process design implemented? To what extent has the chosen process design and implementation been effective and resulted in an acceptable process outcome? Which factors have played an important role in this? Finally, what general lessons can be derived from this case study for design and implementation of public participation programs for regional water management in the Netherlands and elsewhere?

The next section outlines the methods and data used to answer these questions, followed by a presentation of relevant evaluation results from our case study. The discussion will critically reflect on the results and focus on advice for water management practitioners who wish to organize participatory processes. 
Fig. 1. Nested design of the Kromme Rijn participatory groups.

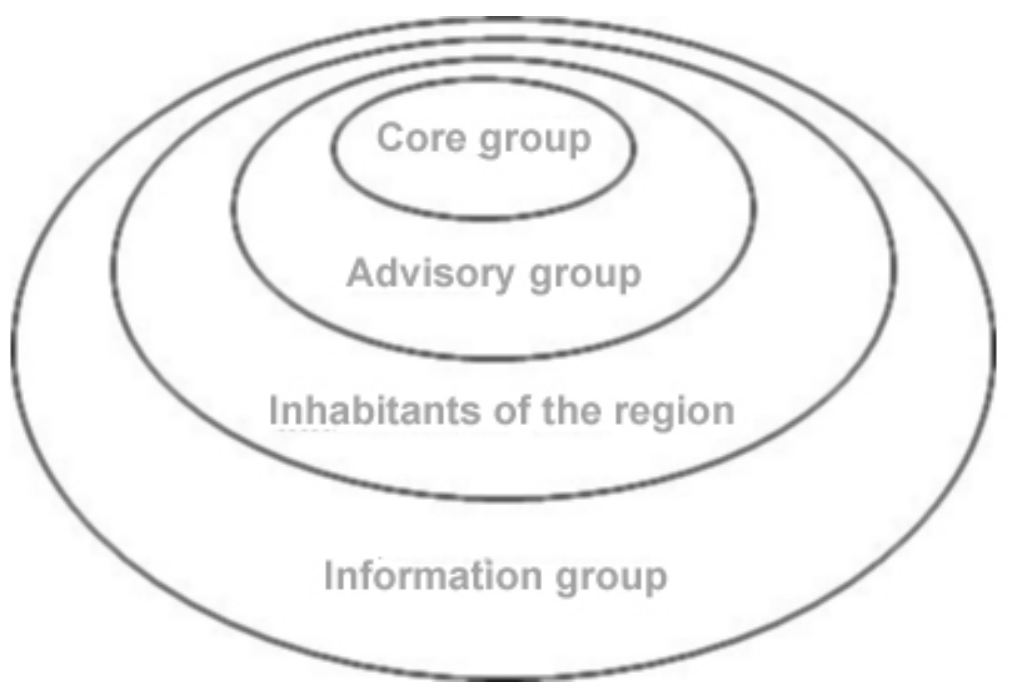

\section{METHODS AND DATA}

The authors were involved in the Kromme Rijn project from the outset: we advised the water board on the design and implementation of the participation program, facilitated discussions between conveners and participants, and evaluated the process. The observations, documentation, and evaluation results collected throughout the process for the different groups in the process design serve as data sources in this article.

We organized interviews with the planning group in different phases of the process. Members of the planning group were considered sufficiently aware of the process design and its implementation and, therefore, capable of providing direct views on the effectiveness and the outcomes of this approach. Interviews were organized in two rounds during the process. During the first round, interviewees were asked about the water board's management style and institutional setting, how it usually organizes participatory processes and the differences with the current approach, and the experience with participatory processes. For accuracy and reliability, interviews with the water board were audio recorded (Robson 2001). Interview reports were sent back to the interviewees for approval and comment. During the second round, questions specifically focused on the effects and difficulties of the process. Anonymity was guaranteed to all interviewees and consequently a coding system is used for referencing in this paper; interviewees are referred to here by the acronyms $\mathrm{PG}, \mathrm{CG}$, and $\mathrm{AG}$ followed by a number identifying the individual. Table 3 provides an overview of all interviews and the coding system.

In addition, the planning group and core group members were evaluated halfway and at the end of the process using a reflection workshop organized by us. Participants included the planning group, water board employees, province and municipal authority representatives, and researchers (including the first three authors). Participants reflected individually on lessons learned during the project's first phase about preparation and execution of the various stakeholder meetings. Subsequently, these lessons were discussed among the participants. On this basis, joint lessons were defined and implemented in the second part of the process. Reflections of the second workshop resulted in organizational lessons and recommendations for future participatory processes. The authors took minutes of the workshops.

Questionnaires and interviews were conducted with advisory group members (including the core group members present). As the members of these groups were not involved in the process design and 
Fig. 2. Design of the Kromme Rijn process.
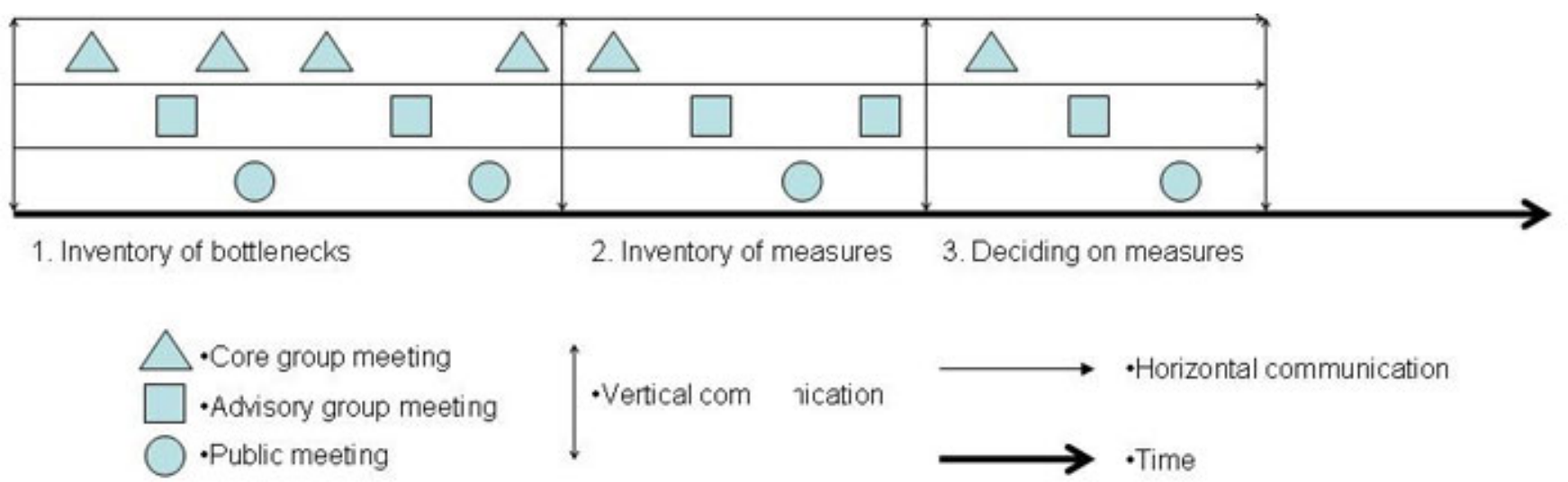

implementation, we felt that asking direct questions would not yield substantive and reliable answers. To evaluate the participants' views, we used a set of standardized performance indicators derived from two key publications in the participation literature (Rowe and Frewer 2000, Beierle and Cayford 2002). According to Beierle and Cayford (2002), distinction has to be made between context factors, referring to "the features of a given situation that a public participation process confronts"; process criteria, referring to conditions that determine "what actually happens" during the process; and the broad set of results that are produced (Beierle and Cayford 2002). Rowe and Frewer (2000) focus on process criteria and distinguish between those factors that "are related to effective construction and implementation" and those that are "related to the potential public acceptance of a procedure" (Rowe and Frewer 2000). We combined the two approaches, adopting Beierle and Cayford's three-phase approach and using Rowe and Frewer's process criteria in the process phase. This set of indicators was administered in a combination of statements and questions by means of questionnaires and telephone interviews. In line with surveying techniques (Neuman 2003), questionnaires were deliberately brief; each questionnaire evaluated no more than 10 indicators. For detailed tables with the evaluation criteria and value ranges, see the Appendix (Tables A1 and A2).
Group members were surveyed in three process phases: at the start, halfway, and at the end. In the first phase, questions and statements referred to contextual factors. In the second phase, the focus was on procedural factors. In the third and final phase, group members were asked about different process outcomes. To improve interpretation of the survey results, additional telephone interviews were conducted in which the participants were asked to provide additional argumentation. In order not to overload them with requests, telephone interviews were organized in two rounds. The context interviews were held several weeks after the context questionnaire; the process and outcome interviews were held jointly toward the end of the process. Interviewees participated on a voluntary basis, confirming their willingness by ticking the appropriate box in the questionnaire. Interviews took place by telephone and resulted in handwritten notes that were typed out and elaborated upon immediately afterward. Five participants volunteered in the first round, four in the second round (see Table 3 ). Three participants were interviewed in both rounds, representing the main user groups involved.

With a larger number of participants anticipated for the public meetings, we opted for a basic standardized questionnaire to be administered during three of the four public meetings. The questionnaire was kept short and evaluated a limited set of statements dealing with procedural factors, such as organization, information delivery, and 
Table 3. Coding of interviewees.

\begin{tabular}{|c|c|c|c|c|}
\hline $\begin{array}{l}\text { Codi- } \\
\text { ng }\end{array}$ & Category & Affiliation / role / position & Interview type (round) & Date / interviewer ${ }^{\dagger}$ \\
\hline PG1 & $\begin{array}{l}\text { Planning } \\
\text { group }\end{array}$ & External consultant / $2^{\text {nd }}$ project leader & Telephone interview (2) & 7-7-2008 / BO \\
\hline PG2 & $\begin{array}{l}\text { Planning } \\
\text { group }\end{array}$ & Water board HDSR / project secretary & $\begin{array}{l}\text { Interview at HDSR (1) } \\
\text { Telephone interview (2) }\end{array}$ & $\begin{array}{l}5-3-2007 / \mathrm{ML} \\
7-7-2008 / \mathrm{BO}\end{array}$ \\
\hline PG3 & $\begin{array}{l}\text { Planning } \\
\text { group }\end{array}$ & Water board HDSR / board member & $\begin{array}{l}\text { Interview at HDSR (1) } \\
\text { Telephone interview (2) }\end{array}$ & $\begin{array}{l}5-3-2007 / \mathrm{ML} \\
7-7-2008 / \mathrm{BO}\end{array}$ \\
\hline PG4 & $\begin{array}{l}\text { Planning } \\
\text { group }\end{array}$ & Water board HDSR / $1^{\text {st }}$ project leader & Interview at HDSR (1) & 22-3-2007 / ML \\
\hline CG1 & Core group & $\begin{array}{l}\text { Municipality Wijk bij Duurstede / policy } \\
\text { maker }\end{array}$ & Telephone interview (3) & 12-3-2008 / ML \\
\hline CG2 & Core group & Province Utrecht / policy maker & Telephone interview (3) & 8-3-2007 / ML \\
\hline AG1 & $\begin{array}{l}\text { Advisory } \\
\text { group }\end{array}$ & $\begin{array}{l}\text { Agricultural organisation (LTO) / local board } \\
\text { member }\end{array}$ & $\begin{array}{l}\text { Telephone interview (3) } \\
\text { Telephone interview (4) }\end{array}$ & $\begin{array}{l}16-3-2007 / \mathrm{BO} \\
5-11-2007 / \mathrm{BO}\end{array}$ \\
\hline AG2 & $\begin{array}{l}\text { Advisory } \\
\text { group }\end{array}$ & $\begin{array}{l}\text { Fruit farming organisation (NFO) / local } \\
\text { board member }\end{array}$ & $\begin{array}{l}\text { Telephone interview (3) } \\
\text { Telephone interview (4) }\end{array}$ & $\begin{array}{l}15-3-2007 / \mathrm{BO} \\
5-11-2008 / \mathrm{BO}\end{array}$ \\
\hline AG3 & $\begin{array}{l}\text { Advisory } \\
\text { group }\end{array}$ & $\begin{array}{l}\text { Agricultural landscape organisation / local } \\
\text { NGO }\end{array}$ & $\begin{array}{l}\text { Telephone interview (3) } \\
\text { Telephone interview (4) }\end{array}$ & $\begin{array}{l}14-3-2007 / \mathrm{BO} \\
5-11-2007 / \mathrm{BO}\end{array}$ \\
\hline AG4 & $\begin{array}{l}\text { Advisory } \\
\text { group }\end{array}$ & $\begin{array}{l}\text { Agricultural organisation (NFO) / policy } \\
\text { maker }\end{array}$ & Telephone interview (4) & 28-11-2007 / ML \\
\hline
\end{tabular}

$\dagger$ Interviewer is identified by author's initials

appreciation of the public meetings (see Table A7 in the Appendix). The lead author was present at all four public meetings to conduct the survey, observe the process, and take notes.

The interview and reflection workshop material was qualitatively analyzed. A selection of interview quotations is presented in the results section of this article. All material presented in this article was collected in Dutch and translated into English by the authors. Given the small numbers of respondents, results from both surveys are presented in tables of basic descriptive statistics, included in the Appendix. Statistical data will only be used in this article to substantiate the interview results.

\section{RESULTS}

\section{Process implementation}

Over a period of more than 2 years, the different groups met in numerous but separate workshops and meetings. The core group met eight times, including during an additional field excursion. The advisory group met eight times. The inhabitants of the region were invited four times to public meetings where information on the planning process was presented and their input was requested. Members of the information group were kept up to date about the developments in the planning process through newsletters and the website. Table 4 provides an overview of the actual meetings organized, their 
Table 4. Overview of events in the Kromme Rijn participation process.

\begin{tabular}{|c|c|c|c|c|c|}
\hline Date & Aims & Core group & $\begin{array}{l}\text { Consultation } \\
\text { group }\end{array}$ & Inhabitants & $\begin{array}{l}\text { \# of } \\
\text { participants }\end{array}$ \\
\hline 13-01-2006 & $\begin{array}{l}\text { Stakeholder analysis } \\
\text { Planning of the process }\end{array}$ & $\mathrm{X}$ & & & 6 \\
\hline $16-02-2006$ & $\begin{array}{l}\text { Stakeholder analysis } \\
\text { Inventory of bottlenecks }\end{array}$ & & $\mathrm{X}$ & & 15 \\
\hline $16-05-2006$ & $\begin{array}{l}\text { Informing citizens } \\
\text { Inventory of bottlenecks }\end{array}$ & & & $\mathrm{X}$ & 30 \\
\hline 08-06-2006 & Hands-on experience of the region & $\mathrm{X}$ & & & 12 \\
\hline 22-06-2006 & $\begin{array}{l}\text { Reaction bottleneck inventory } \\
\text { Reaction to possible policy measures }\end{array}$ & & $\mathrm{X}$ & & 8 \\
\hline $18-10-2006$ & $\begin{array}{l}\text { Reflection workshop on the participation process and } \\
\text { learning }\end{array}$ & $\mathrm{X}$ & & & 15 \\
\hline $19-12-2006$ & $\begin{array}{l}\text { Translation of reflection workshop lessons in } \\
\text { remaining process }\end{array}$ & $\mathrm{X}$ & & & 6 \\
\hline 25-01-2007 & $\begin{array}{l}\text { Informing stakeholders } \\
\text { Reaction to problem identification Overview of } \\
\text { solutions }\end{array}$ & & $\mathrm{X}$ & & 13 \\
\hline 08-02-2007 & Preparation of upcoming stakeholder meetings & $\mathrm{X}$ & & & 5 \\
\hline $28-03-2007$ & Preparation of the consultation group meeting & $\mathrm{X}$ & & & 5 \\
\hline 29-03-2007 & $\begin{array}{l}\text { Presentation and discussion of status } \\
\text { Preparation of citizens evening }\end{array}$ & & $\mathrm{X}$ & & 13 \\
\hline $11-04-2007$ & $\begin{array}{l}\text { Informing citizens } \\
\text { Reaction to policy direction and measures }\end{array}$ & & & $\mathrm{X}$ & 50 \\
\hline $21-05-2007$ & $\begin{array}{l}\text { Informing citizens } \\
\text { Reaction to possible measures }\end{array}$ & & & $\mathrm{X}$ & 40 \\
\hline $23-05-2007$ & Discuss finalisation of the water management plan & $\mathrm{X}$ & & & 6 \\
\hline $30-05-2007$ & $\begin{array}{l}\text { Informing stakeholders } \\
\text { Discussing the progress }\end{array}$ & & $\mathrm{X}$ & & 14 \\
\hline 04-07-2007 & Discussing the water management plan & & $\mathrm{X}$ & & 14 \\
\hline 20-09-2007 & Deliberate on future steps & & $\mathrm{X}$ & & 20 \\
\hline 26-09-2007 & $\begin{array}{l}\text { Informing citizens about the water plan and } \\
\text { procedures }\end{array}$ & & & $\mathrm{X}$ & 65 \\
\hline 27-03-2008 & Evaluation of the consultation group & & $\mathrm{X}$ & & 14 \\
\hline $12-12-2008$ & $\begin{array}{l}\text { Reflection workshop on the institutional lessons for } \\
\text { the water board }\end{array}$ & $\mathrm{X}$ & & & 22 \\
\hline
\end{tabular}


main aims, and the number of participants. It shows that central groups were organized as planned before peripheral groups. Table 5 provides details on the number of participants from central groups participating in the peripheral groups. More than $20 \%$ of the advisory group meetings consisted of core group members; almost $14 \%$ of the participants at public meetings also participated in advisory group or core group meetings.

During the first year of the process, the advisory group meetings were organized in parallel with another participatory program focused on defining a good ecological status for the Kromme Rijn basin (i.e., WFD implementation). Organizing for these meetings to be held in conjunction minimized the workload of the stakeholders participating in both projects. In the second year of the process, the WFD Kromme Rijn implementation project was finished, and water management plan meetings were organized independently.

At the reflection workshop at the end of the first year, a number of lessons were drawn that related to the implementation of the process design. Participants expressed the need for greater clarity about project boundaries and the roles of the water board, the researchers, and the core group members in the process. It was suggested that the core group meetings should clarify these issues before moving to the advisory group and the public. Also, an additional organizational element was added to the process design in the second year of process implementation. Central groups were asked to coorganize the meetings for the peripheral groups to stimulate joint project ownership (see Table 4). The existence of multiple roles and the resulting confusion was also discussed. The water board, acting as convener, stakeholder, and technical expert in the process, became aware of the difficulty in expressing and defending their own interests while performing these other tasks. The authors drew a similar conclusion about their roles of process facilitator, researchers, and process evaluator. From the next meetings on, these roles were more clearly divided between different people. Due to activities elsewhere, the project leader was replaced by a consultant external to the water board at the start of the second year. Also, the second year of the process saw a more active involvement of a water board executive council member in the stakeholder meetings.

The participation process was completed approximately 2 years after its inception with the drafting of the water management plan (see Koenraadt et al. 2008). Key elements of the plan are to widen ditches and canals in the Kromme Rijn Region to ensure sufficient levels of surface water to facilitate water needs of current users; the necessary land will be acquired based on voluntary sales; water extraction permits for additional future users will be assessed based on the capacity of the water system. After 2 years, progress will be reviewed and the water board will decide on options for continuation, including ending the facilitation of specific user needs, invoking article 12 of Dutch water legislation ("Waterstaatswet 1900") that provides legal means for obtaining land for water management under certain conditions, or looking for alternative ways to deliver the necessary water quantities (Koenraadt et al. 2008). The official participation round of the WMP generated more reactions and amendments than usual, which was seen as an indication that the participatory effort had increased awareness of the policy process in the region (PG2). In February 2008, the Water Board's General Council approved the Kromme Rijn WMP. Thereby the water board succeeded in its first objective, i.e., to develop a water management plan with and for the region. After the official approval, evaluative meetings were organized for the advisory group, the core group, and the planning group. In the following sections, we present the results that highlight how successful the process has been in the eyes of participants and organizers; and which factors played a role.

\section{The planning group}

For the most part, interviews with the planning group suggest that the process design and implementation were effective in this case. The process design enhanced the participants' understanding of project boundaries and roles of the actors in the different layers of the process. It also made the core group responsible for setting the project boundaries. According to planning group members, the task was completed satisfactorily in the second half of the first year. "The Province [the regional authority in the Netherlands-ML] was important in the core group because of its role in spatial planning and ground water management. Representation of the municipalities differed. One municipal representative was very good and had a positive contribution in representing the interests of the citizens" (PG2). Furthermore, two planning group members claimed that the role of the core group became less prominent during the second 
Table 5. Details on central group members participating in peripheral groups.

\begin{tabular}{lccc}
\hline \hline Advisory group meeting (AGM) & $\begin{array}{c}\text { Number of } \\
\text { participants }\end{array}$ & Number of CG members & Share (\%) \\
\hline AGM 1 & 25 & 5 & 20.8 \\
AGM 2 & 6 & 1 & 16.7 \\
AGM 3 & 9 & 3 & 33.3 \\
AGM 4 & 11 & 2 & 18.2 \\
AGM 5 & 12 & 2 & 16.7 \\
AGM 6 & 11 & 4 & 18.2 \\
AGM 7 & 13 & 2 & 30.8 \\
AGM 8 & 12 & & 16.7 \\
Total average & & & 21.4 \\
& & Number of CG and AG & Share (\%) \\
Public meeting (PM) & members & 16.7 \\
\hline PM 1 & participants & 5 & 10.0 \\
PM 2 & Appr. 30 & 5 & 15.0 \\
PM 3 & Appr. 50 & 6 & 13.9 \\
Total average & Appr. 40 & & \\
\hline
\end{tabular}

year. This was because most strategic discussions occurred in the advisory group from then on.

The division of individual and sectoral interests in the public meetings and the advisory group was also seen as being beneficial to the process. "Farmers are hard to represent by agricultural organizations," said one planning group member. "Eventually, measures have to be taken on the land of individual farmers. Measures may be in the interest of the agricultural sector as a whole, but not in the interest of the individual farmer. The farmer will be against such measures. That is why the nested nature of the process is important" (PG1). Participants also claimed that they benefited from a safe setting. "In a small group, like the advisory group, things can be discussed more directly and openly because of the sense of safety" (PG2). In other words, open discussion was encouraged between advisory group members and organizers, without risking emotional reactions. Also, compared with other planning processes, the Kromme Rijn discussions were more open, leading to less resistance. The planning group believed that the process created trust between the participants and the water board.

Planning group members reported that their confidence grew as ideas were examined in depth in the core group and advisory group. "The effect of the advisory group on the public meetings was mainly that we were better prepared. There were fewer surprises. This meant we were more confident of making a good presentation and responding well to citizen's questions" (PG2). 
It was felt that all the groups comprised a fair representation of the stakeholders affected by the process, with the exception of the core group, where it was thought that the municipalities were not represented by the appropriate experts. The planning group interviews clearly show the importance of the right representation of interests in the groups and the importance of having participants with the right skills to represent those interests. This was also considered true for the planning group itself. "A lot of it depends on the right people - knowing what your role is. If we had had non-qualified people in key positions it would not have worked. One has to know what to do" (PG3). The experience of the external project leader and the facilitator in the participatory programs was considered an especially important factor for the project's success.

From the planning group's perspective, the process was intensive, with many meetings for different groups. The process was also cost effective, in the sense that the time and money spent were satisfactory for the results achieved. The cost effectiveness became especially clear when it was compared with other water board planning processes. "In a neighboring planning process organized by the water board, only four advisory group meetings were held in 6 years' time, and no public meetings. They are not even ready yet" (PG2). As well as having achieved its main objectives, the process had valuable learning lessons for the water board. "This project has been very important internally for the water board. We are busy changing from a technical organization to a policy organization and this is not easy. There are still people within the water board who would rather just tell stakeholders what will be done and why. I have tried to change the water board into a more communicative agency for 5 years. This project has made the staff proud. It is a pity that we do not have more people who know how to organize such a process" (PG3).

\section{The advisory group}

The results of the advisory group evaluation consist of both qualitative and quantitative information on a wide range of process factors. Below, we present the main interview results and make reference to the survey results included in the Appendix.

Interviewed members affirmed that having different groups organized according to levels of involvement led to fewer conflicts of interests. One interviewee said "This is a good way of planning. First discuss the opportunities and threats with important stakeholder groups, and then discuss the details with the public" (AG1). Advisory group discussions focused on the interests of whole regions, whereas public meetings were reserved for discussions of personal interests. Several advisory group members were also personally affected by the WMP. One such stakeholder said: "You look at the problem from a bird's eye view: more at the collective interest and less at your personal interests" (AG1). The differing results of the context and the outcome questionnaires indicate that, over the course of the process, the advisory group became more positive regarding the conflicting interests and the interest in reaching the group's objectives (see Tables A4 and A6 in the Appendix).

Participants were also very satisfied with the level of openness in the process. "The water board tried to influence the process but in a good way. They determined the scope and the objective of the discussion, but not in a way that did not allow participation. The level of participation was good" (AG3). Too much openness too early in the process was repeatedly mentioned as detrimental to effective stakeholder participation: "Stakeholder involvement should not have taken place earlier. There were too many obscurities. Maybe it could have been later, but then there would have been difficulties as well" (AG2). One interviewee said that "there was a fair amount of feedback among the different groups: the planning group, the advisory group, and the public. Interaction among the advisory group participants was very good. As advisory group members, we had the feeling that we were involved; and not just confronted with facts and decisions" (AG4). The context survey outcome indicates that the openness of the water board was the most positively valued factor at the start of the process, despite existing doubts (Appendix: Table A1). Moreover, process factors, such as unbiased organization, early involvement, real influence, and transparency, were all considered to be positive (Appendix: Table A5).

According to core group members in the advisory group, the openness of the process created trust in the planning group. "There is trust between the participants and the water board because discussions are open. This is mainly due to the way the water board organizes these meetings. At the start, the participants are suspicious; they have a 'seeing is believing' attitude. By subsequently 
allowing people to share their ideas and taking them seriously, trust is built" (CG2). One advisory group member stated that this new trust meant that "the process in the advisory group and the public meetings created support for the water management plan" (AG3). The survey results supported this: participants seemed undecided on the trust of the advisory group in the water board (Appendix: Table A4), whereas the outcome questionnaire clearly showed an increase in trust in the water board from the start to end of the process (Appendix: Table A6).

There was consistent agreement that the representation of stakeholder groups in the advisory group was fair given the group's objective. Participants' fair representation and level of experience was confirmed by the context and process survey results (Appendix: Tables A4 and A5). However, interviewees reaffirmed the importance of proper representation in the process. "It is important to remain critical about who can participate in what group: Do they have enough background knowledge and support? In this water management plan, this worked really well" (AG3). Also, the involvement of an external project leader and an experienced water board council member were mentioned as important factors. "I think the culture of participation is very important. The level of openness for participation differs per person or organization. If there's openness, conveners are flexible to react to developments. What is important is the approach of individual persons in the process" (CG1).

The advisory group indicated overall satisfaction with the effectiveness of the process. The results of the process and outcome questionnaires confirmed that it was considered well managed on the practical level, provided sufficient information and time, and achieved results that could not have been reached more easily otherwise (Appendix: Tables A5 and A6).

However, some interviewees voiced criticisms about the process. One interviewee indicated that the process could have succeeded with "one or two meetings" fewer (AG1). Another interviewee stated that the financial compensation of advisory group members was not consistent. "It was worth the investments for the NFO [Netherlands Fruit Farming Organization]. I would like to note that the LTO [Agricultural Organization] representatives are not getting paid for these meetings. NFO is paying people if it knows that they were there. This would be a problem if this approach is to be repeated in the future. Going to meetings is quite costly for stakeholder group representatives. Maybe part of the process can occur on a closed website on the internet-but then the group dynamics would be missing, which is also essential" (AG4).

\section{The public meetings}

Although the evaluation of the public meetings was not focused specifically on answering the research questions, it did provide insights (see results in Tables A8 and A9 of the Appendix). The evaluation results indicated that participants became more aware of the goal of the meetings as the process progressed. Furthermore, participants found the public meetings useful for understanding the content of and different interests in this water management plan, and for sharing views. Finally, participants clearly regarded their involvement in the planning increasingly important.

\section{DISCUSSION}

In this section, we discuss the results and highlight several practical lessons that can be learned from the Kromme Rijn process in terms of designing and implementing a participatory planning process in a regional water management setting. Overall, the results of the planning group interviews, the evaluations of the advisory group and public meetings, as well as our own observations, suggest that the Kromme Rijn planning process was effective. The outcome of the process was a regional water management plan that considered different stakeholder interests. The plan has been approved by the water board and has now moved into the implementation phase. Moreover, all the main groups involved in the process evaluated the process in a generally positive way. A range of standardized context, process, and outcome criteria confirms that, despite major conflicting interests and doubts at the outset, the process has resulted in a range of satisfactory outcomes. The process of participation seems to be able to overcome conflicting contextual conditions (see also Beierle and Konisky 2000).

We believe that the process design played an important role in reaching a successful process and outcome in this participatory program. The results demonstrate that productive conditions were created for effective horizontal communication in 
all groups. These effects are most clearly observed in the advisory group process, as this group was the main discussion platform and most intensely observed and evaluated. Conflicting interests in the advisory group became most prominent during the second half of the process when the water board made its own position more explicit. It was recognized that the current water system is not capable of supplying sufficient water quantities to meet the demands of the fruit farming sector. Confidence in the planning group and discussions in the core group helped clarify the position of the water board in this planning process. The open atmosphere in the advisory group enabled them to thoroughly discuss the issues before communicating them to the public. Despite a number of regrettable policy measures for individual land owners (i.e., expropriation of land for widening canals), the participants in the advisory group and public meetings assert that they understand the necessity of these measures. The importance of openness and transparency in building trust reflects the existing literature (Marks 2004, Mostert et al. 2007). The results show that vertical communication between the groups was mainly facilitated through the planning group. Planning group members confirm that their confidence in the content grew as a result of intense discussions between the different groups. Results of both the advisory group and the public meetings indicate that the information provided in the form of maps and presentations at meetings improved as the process progressed. Participants of central groups were generally eager to participate in peripheral groups. A possible explanation for this is that members of the central groups were involved in preparing for peripheral group meetings, which made them curious about discussions and outcomes. The importance of design in participatory planning calls for allocating sufficient time and resources to the design phase in participatory planning.

It should be noted that our analysis is only informed by organizers and participants directly involved in the process who voluntarily agreed to participate. We do not know if participation in the core group or advisory group has stimulated participants to communicate more with their constituency about the planning process and the water management plan, or if they became disassociated (Groot et al. 2002). For example, at the final, and unfortunately unevaluated, public meeting, a small group of farmers protested fiercely against the water management plan. It became clear that these tenant farmers were not informed by the landowners or the water board, were absent during earlier meetings, and were now confronted with an unfavorable plan. The water board council member defended the plan, supported by the advisory group members. The incident illustrates the importance of the representativeness of stakeholder processes (Mostert et al. 2007), and in particular, the issue of non-participation (Warner 2005). We argue that as problem frames may change during the process the question of involving the right stakeholders should be addressed not only in the design phase but should continuously throughout the process (see also Glicken 2000). This incident could have been prevented if water board employees who work in the field had been included in these stakeholder analyses.

Another important question is whether the participation process will have positive effects on the longer term, for example during and after the implementation phase. The literature states that the benefits of participatory planning are particularly evident over the longer term (Creighton 2005, Healy 2006). It is likely that the positive relationships that have been developed during the planning process will be beneficial over the longer term. However, these benefits are dependent on the mutual expectations regarding the communication and participation that the water board will undertake during the implementation phase. Empirical evidence for this assumption is not available; the answer to this question lies beyond the current scope and may constitute an interesting follow-up study.

A potential bias in the results may have been generated by the double role of some of the authors in the design, facilitation, and evaluation of the participatory process. Taking on these predominantly neutral roles was necessary for securing access to the process. Interviews were carried out by telephone and on occasion separate from group meetings. The first author-who did not play a major role in process facilitation-alone administered the survey and analyzed the data. The large number of meetings guaranteed that core group and advisory group members were very much aware of the roles and aims of the authors in the process. It would be impossible to not influence the process in action research (Neuman 2003). However, it is believed that triangulation of the diverse data sources collected during the process and several reflection workshops has contributed to a nuanced view on the outcomes. 
The reflection workshops also created a platform for the water board and other water authorities to critically reflect on the process and propose adjustments when necessary. The importance of reflection in governance processes (e.g., Groot et al. 2002, Voss and Kemp 2006), social learning in multi-party collaboration (e.g., Bouwen and Tailleu 2004, Mostert et al. 2007), and adaptive capacity and flexibility of agencies (Folke et al. 2004), are increasingly recognized in the literature as essential elements for sustainable natural resource management. It was clear that the reflection workshop held halfway through the process was crucial in identifying problems during the first half, and allowed organizers to anticipate and rectify these problems for the rest of the process. At the end of the process, another reflection workshop was organized to evaluate lessons learned with the planning group and core group to allow institutional learning for future processes. Both reflection workshops enhanced the planning group's adaptive capacity, both during and after the participatory process, when moving on to new planning projects.

It is clear that participants in the process have not co-decided on the measures proposed in the water management plan. The advisory group was able to co-design and the public was involved for consultation. Different views were discussed openly, but it was not clear how they were integrated into the next draft proposed by the water board. The water board described the project as very pragmatic and aimed to deliver a concrete product under a tight schedule. These forms of limited participation are commonplace in the literature (see Huitema et al. 2009). However, the evaluation data suggest that participants of both the advisory group and the public meetings did not disapprove the water board's influence. In fact, advisory group members claimed that being involved too early when there was no clear proposal to respond to was not favorable. This result is at odds with the criteria of early involvement and real influence advocated in the literature (Rowe and Frewer 2000), but this could be due to the participants becoming more trusting as the agency showed itself to be flexible and responsive to their views (Beierle and Konisky 2000). Warner observes that stakeholders do not necessarily want to take responsibility for comanaging a resource: "They do however want to be heard and not left out of the process" (Warner 2005). Participants often have other responsibilities and workloads that may limit full participation.
At the start of the planning process, advisory group meetings were combined with a pilot project that explored the European Water Framework Directive requirements for the Kromme Rijn basin. Coupling the two projects led to confusion and created a double workload for the planning group and the advisory group. During the second year of the process the two projects were separated, which greatly improved the preparation for the water management plan meetings and clarity for the participants. Clarity of purpose of the public participation and the role of participants in this process is essential for the effectiveness of the process (see also Glicken 2000, Mostert et al. 2007).

Finally, an important factor mentioned in both the planning group and advisory group evaluations were the attitude and experience of those involved in the groups and the planning team. It was repeatedly claimed that the process benefited from a new project leader with extensive experience in similar processes. Also, the involvement of one of us in the planning group and as a facilitator at numerous meetings was mentioned as having a positive influence on proceedings and bringing parties together. These experienced people were external to the water board and played a neutral role in implementing the nested process design. The planning group developed vital communication skills, especially the ability to communicate with stakeholder groups on different levels. According to the water board council member, the water board focuses on providing technical expertise; the staff necessary for running a successful participatory process is, therefore, largely non-existent. Qualified personnel and process leadership are important factors to consider when planning and carrying out participatory planning processes (Olsson et al. 2005, Mostert et al. 2007).

\section{CONCLUSION}

Participatory planning is increasingly seen as an important element in achieving adaptive and integrative water management. Despite more literature on public participation presenting criteria and factors for effective and successful public participation, little is scientifically known about how water managers should proceed in practice. In this article, we presented the Kromme Rijn case, in which a regional water management plan was developed using a participatory approach, based on multiple nested groups. By separating the pool of 
stakeholder interests into a core group of responsible water authorities and an advisory group representing the main user interests and the wider public representing individual interests, the water board planning group aimed to create optimal horizontal communication within groups and vertical communication between groups. This article has shown how and why this process was designed, how it was carried out, how it was evaluated by both the planning group and the participants of different groups, and what role various practical and theoretical design and process factors have played in this project. Data were obtained using different methods for each participatory group and included a mix of open qualitative interviews and focus group discussions, quantitative questionnaires, which evaluated a more standardized range of factors and criteria, and the observations made by us.

Based on analysis of the results, we can conclude that the process design and implementation were effective in the given context. The Kromme Rijn process was generally recognized as a successful participatory project, both by the water board and the participants. Our case study highlights several practical implications in process design and implementation that go beyond the current theoretical literature. First, it is argued that the process design has played an important role in nurturing open and safe discussions in groups, clarity of the roles of both conveners and participants, and a fair representation of interests. In the Dutch context and possibly beyond, organizing nested participatory groups seems to be a potential method to reconcile different types of stakeholder interests toward a common goal.

Another important factor in implementing the process design was allowing for reflective and adaptive moments with the planning group, during and after the process. The process design and implementation depend on a thorough stakeholder analysis aimed at assessing the relationships, interests, power structures, and expected outcomes of a wide array of process players. It is argued that attention should be paid to stakeholder involvement not only in the design phase but throughout the process.

Furthermore, the process implementation has highlighted the experience in participatory processes of the planning group, especially concerning the lack of participatory capacity at technically oriented water boards. Current policy developments require water boards in the Netherlands to move beyond dry feet. With these practical process design and implementation lessons we hope to contribute to this development, as well as the ongoing debate on participatory planning in natural resource management.

Responses to this article can be read online at: http://www.ecologyandsociety.org/voll5/iss 1/art14/ responses/

\section{Acknowledgments:}

The research described in this article was carried out as part of the NeWater project, funded by the 6th Framework Programme of the European Commission (Contract No. 511179 -NeWater). The authors are greatly indebted to water board Hoogheemraadschap De Stichtse Rijnlandenfor the intensive cooperation in this participatory planning project and the stakeholders for their willingness to be interviewed, surveyed, or observed. We are grateful to Pieter Bots, Sabine Moellenkamp, Tharsi, Tailleu, and the anonymous reviewers of this journal for their constructive comments on earlier versions of this article.

\section{LITERATURE CITED}

Arnstein, S. R. 1969. A ladder of citizen participation. Journal of the American Planning Association 3(4):216-224.

Beierle, T. C., and J. Cayford. 2002. Democracy in practice. Public participation in environmental decisions. Resources for the Future Press, Washington, D.C., USA.

Beierle, T. C., and D. M. Konisky. 2000. Values, conflict, and trust in participatory environmental planning. Journal for Policy Analysis and Management 19(4): 587-602.

Bouwen, R., and T. Tailleu. 2004. Multi-party collaboration as social learning for interdependence: developing relational knowing for sustainable natural resources management. Journal of Community and Applied Psychology 14:137-153. 
Creighton, J. L. 2005. The public participation handbook: making better decisions through citizen involvement. Jossey-Bass, San Francisco, California, USA.

Eden, C. 1996. The stakeholder/collaborator strategy workshop. Pages 44-56 in C. Huxham, editor. Creating collaborative advantage. Sage Publications Ltd., London, UK.

European Communities. 2003. Economics and the environment: the implementation challenge of the Water Framework Directive. Common implementation strategy for the Water Framework Directive (2000/60/EC). Guidance Document 1. Office for Official Publications of the European Communities, Luxemburg.

Folke, C., T. Hahn, P. Olsson, and J. Norberg. 2004. Adaptive governance of social-ecological systems. Annual Review of Environmental Resources 30(8):1-33.

Geurts, J., and I. Mayer. 1996. Methods for participatory policy analysis: towards a conceptual model for research and development. Work and Organization Research Centre (WORC). Report 96.12.008/3. Tilburg University, Tilburg, The Netherlands.

Glicken, J. 2000. Getting stakeholder participation "right": a discussion of participatory processes and possible pitfalls. Environmental Science and Policy 3:305-310.

Gray, B. 1996. Cross-sectoral partners: collaborative alliances among business, government and communities. Pages 57-79 in C. Huxham, editor. Creating collaborative advantage. Sage Publications Ltd., London, UK.

Groot, A., N. van Dijk, J. Jiggins, and $M$. Maarleveld. 2002. Three challenges in the facilitation of system-wide change. Pages 199-214 in C. Leeuwis and R. Pyburn, editors. Wheelbarrows full of frogs. Social learning in rural resource management. Koninklijke van Gorcum BV, Assen, The Netherlands.

Hare, M., R. A. Letcher, and A. J. Jakeman. 2003. Participatory natural resource management: a comparison of four case studies. Integrated Assessment 4(2):73-78.
HarmoniCOP. 2005. Learning together to manage together: improving participation in water management. Harmonising Collaboration Planning Project, Europe. [online] URL: http://www.harmon icop.uos.de/HarmoniCOPHandbook.pdf.

\section{Hoogheemraadschap De Stichtse Rijnlanden} (HDSR). 2003. Waterbeheersplan. Hoogheemraadschap De Stichtse Rijnlanden, Houten, The Netherlands.

Healy, P. 2006. Collaborative planning: shaping places in fragmented societies. Second edition. Palgrave Macmillan, New York, New York, USA.

Holtman, M.,A. Menkveld, and E.Addink. 2005. Plan van aanpak watergebiedsplan Kromme Rijn en KRW-pilot waterlichaam Kromme Rijn. Bijlage bij bestuursvoorstel 05.SPR. Hoogheemraadschap De Stichtse Rijnlanden, Houten, The Netherlands.

Huitema, D., E. Mostert, W. Egas, S. Moellenkamp, C. Pahl-Wostl, and R. Yalcin. 2009. Adaptive water governance: assessing the institutional prescriptions of adaptive (co-) management from a governance perspective and defining a research agenda. Ecology and Society 14 (1): 26. [online] URL: http://www.ecologyandsociety. org/vol14/iss1/art26/.

Koenraadt, R., A. Menkveld, M. Stark, and A. Koomen. 2008. Watergebiedsplan tussen Kromme Rijn en Amsterdam-Rijnkanaal. Hoogheemraadschap De Stichtse Rijnlanden, Houten, The Netherlands. [online] URL: http://www.hdsr.nl/aspx/download.aspx? File=/contents/pages/60146/watergebiedsplan tuss en kromme rijn en amsterdam-rijnkanaal.pdf.

Lynn, F. M., and G. J. Busenberg. 1995. Citizen advisory committees and environmental policy: what we know, what's left to discover. Risk Analysis 15(2):147-162.

Marks, J. S. 2004. Negotiating change in urban water management: attending to community trust in the process. Pages 203-215 in T. Daniell, R. James, and K. Takara, editors. Cities as catchmentsWSUD2004. Proceedings of the 2004 International Conference on Water Sensitive Urban Design, 2124 November, 2004, Adelaide, South Australia. [online] URL: www.wsud.org/downloads/Info\%20 Exchange\%20\&\%20Lit/WSUD 04 Conf Papers/ WS040098.PDF. 
Meadowcroft, J. 1998. Co-operative management regimes: a way forward? Pages $21-42$ in $P$. Glasbergen, editor. Co-operative environmental governance. Public-private agreements as a policy strategy. Kluwer Academic Publishers, Dordrecht, The Netherlands.

Moellenkamp, S., M. Lamers, and E. Ebenhoeh. 2007. Institutional elements for adaptive water management regimes. Comparing two regional water management regimes in the Rhine basin. Pages 147-166 in C. Pahl-Wostl, P. Kabat, and J. Möltgen, editors. Adaptive and integrated water management. Coping with complexity and uncertainty. Springer Verlag, Berlin, Germany.

Mostert, E. 2006. Integrated water resources management in the Netherlands: how concepts function. Journal of Contemporary Water Research and Education 135:19-27.

Mostert, E., C. Pahl-Wostl, Y. Rees, B. Searle, D. Tàbara, and J. Tippett. 2007. Soical learning in European river-basin management: barriers and fostering mechanisms from 10 river basins. Ecology and Society 12(1): 19. [online] URL: http://www.e cologyandsociety.org/vol12/iss1/art19/.

Neuman, W. L. 2003. Social research methods. Qualitative and quantitative approaches. Fifth edition. Allyn and Bacon, Boston, Massachusetts, USA.

Newig, J., and C. Pahl-Wostl. 2005. The role of public participation in managing uncertainty in the implementation of the Water Framework Directive. European Environment 15:333-343.

Olsson, P., C. Folke, and F. Berkes. 2005. Adaptive comanagement for building resilience in social-ecological systems. Environmental Management 34(1):75-90.

Pahl-Wostl, C., J. Sendzimir, P. Jeffrey, J. Aerts, G. Berkamp, and K. Cross. 2007. Managing change toward adaptive water management through social learning. Ecology and Society 12(2): 30. [online] URL: http://www.ecologyandsociety.org/vol12/ iss $2 / \operatorname{art} 30 /$.

Renn, O. 1999. A model for an analytic-deliberative process in risk management. Environmental Science and Technology 33(18):3049-3055.
Robson, C. 2001. Real world research. A resource for social scientists and practitioner-researchers. Blackwell Publishers Ltd., Oxford, UK.

Rowe, G., and L. J. Frewer. 2000. Public participation methods: a framework for evaluation. Science, Technology and Human Values 25(1):329.

Rowe, G., and L. J. Frewer. 2004. Evaluating public participation exercises: a research agenda. Science, Technology, and Human Values 29(4):512556.

Rowe, G., R. Marsh, and L. J. Frewer. 2001. Public participation methods: evolving and operationalizing an evaluation framework. Final report to the Department of Health and Health and Safety Executive. Institute of Food Research, Norwich, UK.

Syme, G. J., and B. E. Nancarrow. 2002. Evaluation of public involvement programs: measuring justice and process criteria. Water 29 (4):18-24.

van der Arend, S. 2007. Pleitbezorgers, procesmanagers en participanten. Interactief beleid en de rolverdeling tussen overhead en burgers in de Nederlandse democratie. Eburon, Delft, The Netherlands.

Voss, J.-P., and R. Kemp. 2006. Sustainability and reflexive governance: introduction. Pages 3-27 in J.-P. Voss, D. Bauknecht, and R. Kemp, editors. Reflexive governance for sustainable development. Edward Elgar Publishing Ltd., Cheltenham, UK.

Warner, J. 2005. Multi-stakeholder platforms: integrating society in water resource management? Ambiente y Sociedade 8(2):1-20.

Warner, J., and A. Verhallen. 2007. The nature of the beast: towards a comparative MSP typology. Pages 21-29 in J. Warners, editor. Multistakeholder platforms for integrated water management. Ashgate Publishing Ltd., Aldershot, UK.

Watson, N. 2007. Collaborative capital: a key to their successful practice of integrated water resources management. Pages 31-48 in J. Warners, 
editor. Multi-stakeholder platforms for integrated water management. Ashgate Publishing Ltd., Aldershot, UK.

Webler, T. 1995. "Right" discourse in citizen participation-an evaluative yardstick. Pages 3586 in O. Renn, T. Webler, and P. M. Wiedemann, editors. Fairness and competence in citizen participation-evaluating models for environmental discourse. Kluwer Academic Publishers, Dordrecht, The Netherlands.

Webler T., and S. Tuler. 2001. Public participation in watershed management planning: views on process from people in the field. Human Ecology Review 8(2):29-39. 
Appendix 1. Evaluation results of the advisory group and the public meetings

\section{Please click here to download file 'appendixl.pdf'.}

